\title{
The Influence of Social Media on Arabic Writing Skills among Jordanian $10^{\text {th }}$ Graders'
}

\author{
Al. Fayyoumi, Khalil A. Rahman. M. ${ }^{1 *}$ \\ Al. Fayyoumi, Moaweyah, Khalil. A. Rahman ${ }^{2 *}$ \\ 1.pt. Curricula \& Teaching Methods, Faculty of Educational and Psychological Science, Amman Arab Uni, \\ Jordan. Jordan Street-Mubis- P.O box. 2234 - Amman 11953 - Jordan,. Tel. 0096264791400 \\ 2.hool of Engineering, University of Jordan. Mubis-P.O box. 2234 - Amman 11953 - Jordan, Dr. Fayyoumi \\ Khal, Faculty of Educational and Psychological Science
}

\begin{abstract}
This study aimed to investigate the influence of using social media on the $10^{\text {th }}$ graders' progress in writing skills, and their attitudes towards writing at Naour District in Amman schools, and the effect of gender, academic qualifications, educational and professional experiences. A five-point questionnaire, and a standardized writing test were sophisticated. It included three composition questions to get three paragraphs based on writing. The sample of the randomized study consisted of (1064) students of the $10^{\text {th }}$ grade. The study showed, there were no significant differences in the effect of social media towards writing skills for $10^{\text {th }}$ graders' due to academic qualification on third domain, whereas there were significant differences on the effect of social media towards Arabic writing proficiency due to academic qualification in the first and second domains. There were also statistically significant differences on the effect of social media towards writing proficiency for $10^{\text {th }}$ graders'.
\end{abstract}

Keywords: Social Media, Writing Skills, $10^{\text {th }}$ Graders, Amman schools, Teaching Methods.

DOI: $10.7176 / \mathrm{JEP} / 11-36-18$

Publication date: December $31^{\text {st }} 2020$

\subsection{Introduction}

Writing is one of four language skills that requires attention. It is the process of transforming thoughts and ideas into written communication (Isa, 2012). Abdullah (2015) defined writing as a communicative skill to send, retrieve and store messages with the help of written symbols, as it is a productive language process. Writing can be expressive, poetic, informative and persuasive. Depending on the type of writing, the writer concentrates either on the subject matter of the written piece, on the reader or on one's own feelings and thoughts (Abed, 2012; Isa, 2012) decided that writing is a major classroom procedure. It is an effective technique and process for reinforcing the oral language material, it is important for providing evidence of the students' achievements. Writing proficiency plays a great role in conveying a written message accurately and effectively.

According to Albawe \& Stanley (2014) online learning provides major benefits to both students and teachers. The benefits include convenience, time and geographic flexibility. The internet makes resources more accessible at a low cost. Multimedia tools simulate real task environments, which can motivate learners as well as facilitate learning, the adoption of technology in development, delivery, and administration is not a simple process, which requires minor modification (Albawe \& Stanley, 2014; Mills, 2011). Educators and educational institutions must be aware that it is a fundamental shift of philosophy, policy, and instruction. Isa (2012) showed that elementary students involved in computer-based writing projects increased the level of their communication skills when paired in collaborative writing assignments completed in a technology-based setting, he indicated that learning to write is not just a mechanical process in which students manipulate grammar and words on a page to produce literary works. Social networking is one aspect of social media, interests or are looking to meet people with similar ideas and interests (Isa, 2012). Mhunpiew \& Purayidathil (2015) mentioned that (Allaith \& Joshi, 2008) comprises the activities of social media that involve socializing and networking online.

The researcher believed also based on Isa (2012) study that the need for the study to spring on the following resources: Firstly, the researcher interviewed Arabic teachers who have wide knowledge about student's levels and results, especially in10th grade exams. Most of them agreed on the idea that students suffer from weak main writing skills. Secondly, the lack of researches in this field and new technologies took our teachers and students far away from technology contemporary life. So, the new tendency in Arabic language education focused on integrating technology to teaching and learning process and improving collaborative writing skills.

\subsection{Statement of the Problem}

Teaching and learning writing is not an easy job for both teachers and learners. In the study done by Murad \& Khalil (2015), it is found that native or nonnative speakers of Arabic faced problems and made mistakes in punctuation especially in sentence forming. In a study carried out by the National Commission on Writing (2003), it was found that the diffusion of new technologies, the development of the knowledge. Based on these assumptions, the researcher looks for improving the students' way of writing through using the suitable and enthusiastic way as 
social media.

\subsection{Aim and Objectives of the study}

The present study aims at, investigating the impact of using social media on the $10^{\text {th }}$ graders' writing competence, and their attitudes towards writing in Amman students.

\subsection{Objectives of the study}

More specifically, the study addresses the following objectives:

- Mapping whether social media affects the students writing competence positively or negatively.

- Finding out if there are any significant differences in the student's competence in writing, because of using social media on the $10^{\text {th }}$ graders' writing competence due to gender, social media, writing skill and geographical distribution.

\subsection{Questions of the study}

- What is the effect of using social media on Jordanian $10^{\text {th }}$ graders' Arabic writing proficiency in Amman schools?

- What are the kinds of impact that social media has on the pupils' writing competence?

- What are the effects of social media on the pupils writing proficiency, with respect to gender and location?

\subsection{Hypotheses of the study}

- There are no statistically significant differences at $(\alpha \leq 0.05)$ in the effect of using social media on Jordanian $10^{\text {th }}$ graders' Arabic writing proficiency due to gender.

- There are no statistically significant differences at $(\alpha \leq 0.05)$ in the effect of using social media on Jordanian $10^{\text {th }}$ graders' Arabic writing proficiency due to academic qualification.

- There are no statistically significant differences at $(\alpha \leq 0.05)$ in the effect of using social media on Jordanian $10^{\text {th }}$ graders' Arabic writing proficiency due to educational experience.

\subsection{The Significance of the study}

It is the first study in the field, social media has been introduced to the field of education of writing in Arabic in Jordan. For this reason, the study may be highly significant for:

- Arabic language teachers' intending to implement new steps, procedures, activities and techniques based on technology, i.e. social media to improve students' writing skills proficiency.

- Encouraging and motivating students to use social media to improve their writing skills proficiency.

- Stimulating specialists' and supervisors' interests in conducting training courses for teachers to sustain their skills in using social media in their teaching writing.

- Encouraging syllabus designers to modify, organize and enrich Arabic language curricula with various instructions, techniques and activities for teaching writing based on social media tools.

\subsection{Limitations of the study}

- Locative limitations: The population of the study consists of the $10^{\text {th }}$ graders' schools in the Jordan.

- Temporal limitations: The study is going to be carried out in the second semester during the academic year (2018-2020).

- Human limitations: The population of the study consists of the $10^{\text {th }}$ graders' students at the basic stage in the governmental schools.

- $\quad$ Topical limitations: It conducts social media through using Facebook, twitter, internet, and Google.

\subsection{Operational definitions}

- $\quad$ Social Media: The researcher studies social media, (Facebook, Twitter, Instagram, Email, YouTube, and Google), its effects on the students' writing proficiency. The study agrees with (Petrina, 2007) description for social media as a new information network, information technology using a form of communication utilizing interactive and user- produced content, and interpersonal relationships are created and maintained. Typical social media network services could be content sharing, web communities, and Internet forums.

- Writing skills: According to the table content of $10^{\text {th }}$ grade student book 2017, (4-5), the researcher looks for utilizing writing skills objectives, which are: Write an email, order events into a paragraph, write a report from notes, summarize of a conversation opinions and reactions, write a story, write an informal letter, make a project 
proposal, and write your own message.

- $\quad$ Tenth Graders: The study targets $10^{\text {th }}$ grade students in government schools (male \& female), it is the last grade of the basic education stage.

- Amman schools: The public schools in the directorates of education in the Jordanian capital Amman, number (1121) schools, in the academic year (2018-2020).

- $\quad$ Teaching Methods: The actual teaching methods used by the Arabic language teachers in teaching Arabic subjects in the Naour area.

\subsection{Conventional Classroom Instructions}

In the conventional education, the researcher finds nonnative teachers in the Jordanian schools teach students without understanding what they taught for and missing technology in teaching writing skill as (Robert, 2009) defined the conventional education as it focuses on teaching, not learning.

\subsection{Experimental Classroom Instructions}

In the experimental classroom, the researcher selects students use social media " Facebook, twitter, Instagram, email, YouTube and Google " in different conditions. Some of the students learn Arabic writing skill through social media, the others don't use social media in learning, so the study tested the students' writing proficiency through using the written test to see whether they are in their positions or not. The researcher tries to keep in touch with the new technology especially in teaching Arabic writing skills proficiency.

\subsection{Introduction and Theoretical Background}

\subsubsection{Part One: Related Literature}

Using social media tools in teaching sometimes can be very challenging to instructors. Students can be a very good consulting source, because they are the experts and they have a better understanding of the tools (Sabine, Kinshuk \& Liu, 2009). Crook (2008) cited in White (2004) added that social media tools provided learners with new opportunities to become independent in their study and research. They encouraged a wider range of expressive capacity. Sabine, Kinshuk \& Liu (2009) stated "The future technology integration in education should focus on what students use instead of what the school wants them to use to guarantee maximum efficiency. The researcher presented related literature and related studies that address the positive and the negative effects of social media on the $10^{\text {th }}$ graders' writing proficiency. In a study about conducted on the impact of social networking on new age teaching presented that social media create a new community where teachers and students do not have to communicate by means of the traditional face-to-face classroom environment (Easton, 2003).

Junco (2007) emphasized that online discussions direct teenagers into self- learning and create opportunities for them to develop critical thinking and argumentation skills. Virtual communication could potentially enhance its user's social understanding and offer positive influences (Nassar, 2016). Whereas Wheeler (2009) added that learners will not find it comfortable to learn with their teachers over their shoulders. Besides Langer (2014) added that social media has several effects on academic work. It also has a positive impact on student's sense of themselves in the community, Sharawneh (2012) agreed that the proficiency of the writing skill of language teachers and students has always been important because the results of such an effect are used for a variety of administrative, instructional and research purposes. Classroom teachers benefit from these results. They use these results to help improve, influence, refine and shape their students' attained writing ability. (Duncan \& Barnett, 2012) found that, besides the roles of directing and leading the online learning class to reach the goal, the online teachers also had to be aware of a balance of flexibility of the teaching time and problem-solving tasks that might occur anytime while working on a lesson.

Social media includes activities such as socializing and networking online through words, pictures and videos. Also, it is redefining how it is related to teach other as humans and how humans relate to the organizations that serve us, (Murad \& Khalil, 2015; Fareh, 2014) stated that students learn more in less time when they receive computer- based instruction and the use of technology in higher level reasoning and problem-solving abilities. Harmer (2004) found that one of the positive influences is that the internet plays a vital role in providing teenagers with multi- connected networks across the globe. It sets the basis of a virtual world, one which exists without faceto-face interactions which may cause the learners especially the shy ones feel embarrassed from their classmates.

The researcher believed also based that the need for the study to spring on the following resources: Firstly, the researcher interviewed Arabic language teachers who have wide knowledge about student's levels and results, especially in (8) exams. Most of them agreed on the idea that students suffer from weak main writing skills. Secondly, the lack of researches in this field and new technologies took our teachers and students far away from technology contemporary life. So, the new tendency in Arabic language education focused on integrating technology to teaching and learning process and improving collaborative writing skills. 


\subsubsection{Teaching Writing through Social Media}

Khailani \& Muqattash (1996) mentioned five pedagogical purposes for teaching writing. The researcher found many purposes for teaching writing through social media to students that affected on their language development, learning style, and writing as a skill. Stephanie (2015) discussed a three- phase framework of teaching to write: firstly, pre-writing: schemata- the previous knowledge a person already has activation, motivation for writing, preparation for the writing and familiarization with the format of the text. Secondly, while writing thesis development, writing from notes, proceeding from a given beginning phrase and following a plan. Thirdly, postwriting: reflection on spelling and grammar errors, sharing the writing with other students-redrafting, peer editing. Lindsay \& Knight (2006) suggested that teachers should divide writing activities into three stages:

According to Byrne (1997) writing is considered difficult even in the mother tongue because of these three factors; psychological, linguistic, and cognitive. From the psychological side, when students write, they write on their own selves because it is a solitary activity, so students must write without possible interaction or feedback. Hence, writing is considered difficult.

About the cognitive problem, students learn to write through a process of instructions. To do so, students must master the written form of the language and to learn the structures of writing, which are not used in speaking. Students also must learn how to organize their ideas in a way by which a reader can absorb it without being present or knowing the writer. It is known that writing is a difficult skill as it is a productive skill. The students suffer when they are asked to write, so the need to develop students' writing skills by utilizing social media considered an important study.

\subsubsection{Part Two: Related Studies}

Alshrouf (2018) conducted a study aimed at discovering the effect of using internet on improving writing expression and oral expression skills in Arabic language course among basic ninth class students. The sample consisted of (60) male and female students, were the schools selected purposely. The study sample divided into two groups: experimental group, and control which. As well as the researcher-built writing expression exam and oral expression exam. The study results unveiled that there is an effect of using internet on improving writing expression and oral expression skills in Arabic language course among basic $9^{\text {th }}$ class students.

Tezci \& Icen (2017) research aims to determine social media usage habits of high school students. The results show that the most used social media among the students participating in questionnaire is YouTube, and Facebook, follows it in the second place, Myspace, and LinkedIn, are the least used social media sites. Gender differences has an important impact on social media usage. Students access and use social media mostly with using their smartphones; students spend between (1-3) hours daily on social media.

Reershemius, Gertrud (2017) in article analyses how speakers of an autochthonous heritage language (AHL) make use of digital media, through the example of Low German, a regional language used by a decreasing number of speakers mainly in northern Germany. The focus of the analysis is on Web 2.0 and its interactive potential for individual speakers. The study therefore examines linguistic practices on the social network site Facebook, with special emphasis on language choice, bilingual practices and writing in Low German. The findings suggest that social network sites such as Facebook have the potential to provide new mediatized spaces for speakers of an AHL that can instigate sociolinguistic change.

Ghanem M (2016) conducted a study about the impact of using google applications as a vehicle to increase sixth grade students' scientific concepts acquisition and their attitudes toward the acceptance of technology. The study employed the quasi-experimental design with two groups: experimental and control. The sample size is 140 students. The control group taught using the regular method, and the experimental group taught using google apps. The results revealed that there were no statistically significant differences at $(\alpha \leq 0.05)$ level between the mean scores of the experimental group, and the control group in achievement test, the researcher recommended the ministry of education to adopt google apps for one year at least to show more.

Alshohry (2014) conducted a study about the effects of using electronic social networks on social relationships "Facebook and Twitter. The study showed several results including: The most important reasons urging students to use Facebook and Twitter are freedom in expressing their opinions and exchanging ideas which cannot be expressed in their societies. The results proved positive relationship between method of use variable and social relationships nature, merits and demerits.

Isa (2012) conducted a study about the Effect of Using Wikis on Improving Palestinian 9th Graders' Writing Skills and their Attitudes towards Writing". The study aimed to examine the impact of using wikis on the $9^{\text {th }}$ graders' improvement of writing skills and their attitudes towards writing, and to enhance English language teacher's competencies in using wikis on improving their students' writing skills. Moreover, the study findings revealed that there were significant differences between the scores attained by the experimental group and the controlled group in favor of the experimental group. This was due to the wiki technology. The study recommended that teachers were asked to use the wiki technology in teaching writing skills to develop and improve their students' ability in writing skills.

Kissler (2010) conducted a study about connect. ED: Social media became a powerful tool for creating and 
sharing in conversations with people next door and around the globe. This recent generation of tech-savvy and highly engaged individuals was the most connected group on the planet. They gathered information from a variety of sources and were quick to identify false messaging. Messages were delivered in seconds to networks of hundreds and thousands of individuals who were all listening to that new form of "word of-mouth" communication. This research explored the difficulties current and prospective students were having with higher education, the characteristics of Millennial.

\subsection{Methodology}

A descriptive approach statistical analysis was used to achieve the main purpose of the study as well as to answer the research questions. The researcher studied two tools of the study namely questionnaire and standardized writing test to fit the variables and the hypotheses of the study.

\subsection{Population of the study}

The population of the study consisted of: The total number of the $10^{\text {th }}$ Arabic language teachers in the Education Naour District in Amman is (136) during the second semester, for the scholastic year 2019-2020. The total number of the Arabic language male and female teachers in the Naour area, which was extracted from the Statistics Manual-Ministry of Education in Jordan. The total number of the $10^{\text {th }}$ graders' male and female in the Naour District at the governmental schools is (1064) during the second semester, for the scholastic year (2019-2020). The statistical total number of the $10^{\text {th }}$ graders' number in the Naour District which was taken from the Statistics Manual-Ministry of Education.

\subsubsection{Sample of the study}

The researcher based on these sampling techniques. He selected a sample of total percentage (20\% out of 1064$)$ of the Arabic language teachers from the whole population. Tables (1- 3) below shows the sample distribution in accordance with the three independent variables: gender, Academic Qualifications, Educational Experience, in teaching Arabic.

Table (1): Distribution of Arabic Teachers sample, \& student according to gender

\begin{tabular}{|c|c|c|c|c|c|}
\hline Gender/Teachers & Frequency & Percentage & Gender/Students & Frequency & Percentage \\
\hline Male & 74 & 54.4 & Male & 591 & 55.5 \\
\hline Female & 62 & 45.6 & Female & 473 & 44.5 \\
\hline Total & 136 & $100 \%$ & Total & 1064 & $100 \%$ \\
\hline
\end{tabular}

Table (2): Distribution of Arabic Teachers Sample According to Academic Qualifications

\begin{tabular}{|c|c|c|}
\hline Academic Qualifications & Frequency & Percentage $\%$ \\
\hline Bachelor & 113 & 83 \\
\hline Master & 023 & 17 \\
\hline Total & 136 & $100 \%$ \\
\hline
\end{tabular}

Table (3):Distribution of Arabic Teachers Sample According to Educational Experiences

\begin{tabular}{|c|c|c|}
\hline Educational Experience & Frequency & Percentage \\
\hline Less than 5 years & 16 & 11.8 \\
\hline 5-10 years & 43 & 31.6 \\
\hline More than 10 years & 77 & 56.6 \\
\hline Total & 136 & 100 \\
\hline
\end{tabular}

The researcher selected a sample of total (240) $10^{\text {th }}$ graders, from the whole population where chosen based on the sample, that is divided into two groups: the experimental group that used the written social media "Facebook, twitter and e-mails ", and the control group that used the oral social media "Instagram, google and YouTube."

\subsection{Tools of the study}

The two tools namely a questionnaire and standardized writing test to answer the questions of the study:

4.1.1. The questionnaire consisted of two sections: The first section consisted of personal information about teachers' Gender, Academic Qualification, Educational Experience, in teaching Arabic language. The second section consisted of the (26) items to measure the effect of social media on Jordanian $10^{\text {th }}$ graders' Arabic writing proficiency. The standardized writing test consisted of two sections: The first section consisted of personal information about the $10^{\text {th }}$ graders' Age, Gender, using computer, Governorate, the first semester average, Average 
in Arabic, School, using written social media, using oral social media, using social media intensively, one or two hours daily and Using social media at least two hours in a week. The second section consisted of three composition paragraphs to measure the effect of social media on Jordanians $10^{\text {th }}$ graders' Arabic writing proficiency.

\subsubsection{Validity of the Tools}

The questionnaire and the standardized writing test were developed based on the need of the study to a jury in the field of Arabic language instruction in the University of Jordan. Some modifications have been based on the vocabulary such as "utilizing" instead of "using", "proficiency" instead of "competence" and adding the last item

" The more the students use the social media, the better their writing competence."

\subsubsection{Reliability of the Tools}

The Cronbach Alpha coefficient was used to find out the reliability for both the three domains of the questionnaire and total score. Table (4) shows reliability coefficients of each domain and the total score "degree" of the study.

Table (4): Reliability coefficients of each domain and the total score of the study

\begin{tabular}{|l|c|c|}
\hline \multicolumn{1}{|c|}{ Domains } & $\begin{array}{c}\text { Number of } \\
\text { items }\end{array}$ & $\begin{array}{c}\text { Reliability } \\
\text { coefficient }\end{array}$ \\
\hline $\begin{array}{l}\text { The students' attitudes towards using social media as a tool of writing of } \\
\text { Arabic language. }\end{array}$ & 9 & 0.864 \\
\hline Type of impact & 9 & 0.722 \\
\hline The effect of social media on students' writing proficiency. & 8 & 0.742 \\
\hline \multicolumn{1}{|c|}{ Total score } & 26 & 0.852 \\
\hline
\end{tabular}

Table (4) shows that all the reliability coefficients are high, and suitable for scientific purposes.

\subsection{Procedures of the study}

5.1.1. Preparing the study tools and establishing the validity and reliability of the tools by the experts in the field of Arabic language instruction at the University of Jordan, who are approved the utility of the tools for carrying out the study, the researcher studied and adopted the observations and suggestions proposed, and made the amendment, addition and deletion.

5.1.2. The researcher collected the needed statistical data and defined the population of the study from the Statistics Manual-Ministry of Education in Jordan.

5.1.3. The researcher distributed the questionnaire in the first semester for the scholastic year 2019- 2020 . (136) teachers were asked to answer the questionnaire. A week later, the researcher began to collect the questionnaires from the Directorates of Education. To estimate the teachers' responses toward the effect of social media on Jordanian $10^{\text {th }}$ graders' Arabic writing proficiency, the researcher adopted the Likert's five-level scale and used the following scales, depends on percentage as follows:

- $\quad 80 \%$ and more, is a very high degree.

- $\quad 70-79.9 \%$, is a high degree.

- $\quad 60-69.9 \%$, is a moderate degree.

- $\quad 50-59.9 \%$, is a low degree.

- $\quad 49.9 \%$ and less, is a very low degree.

5.1.4. The standardized writing test was distributed in the second semester for the scholastic year 2018-2020, (120) students were asked to answer the standardized writing test. Three weeks later, the researcher collected the tests to estimate the $10^{\text {th }}$ graders' responses toward the effect of social media on Jordanian $10^{\text {th }}$ graders' Arabic writing proficiency.

\subsection{Conclusion}

6.1.1. Results related to the study questions

\section{Results Related to the first question}

- $\quad$ What is the effect of using social media on Jordanian $10^{\text {th }}$ graders' Arabic writing proficiency in Amman schools?

Table (5) shows the results. 
Table (5): Means, standard deviation, percentages and levels of students' attitudes towards using social media as a tool of writing in Arabic language

\begin{tabular}{|c|c|c|c|c|c|}
\hline & Item & M & SD & Percentage & Level \\
\hline 9 & Students work well in their groups through social media. & 3.62 & 1.02 & 78.4 & High \\
\hline 8 & $\begin{array}{l}\text { Students prefer to write in Arabic by } \\
\text { using social media. }\end{array}$ & 3.81 & 1.08 & 76.2 & High \\
\hline 7 & $\begin{array}{l}\text { Students are motivated to write activities through atypical } \\
\text { Arabic social media language writing. }\end{array}$ & 3.68 & 1.04 & 72.8 & High \\
\hline 6 & Students like to write collaboratively through social media. & 3.64 & 1.05 & 76.2 & High \\
\hline 1 & $\begin{array}{l}\text { Students can write activities in Arabic through utilizing social } \\
\text { media. }\end{array}$ & 3.72 & 1.02 & 72.4 & High \\
\hline 5 & $\begin{array}{l}\text { Students write more if the social media issued as a } \\
\text { supplementary tool. }\end{array}$ & 3.69 & 1.06 & 71.4 & High \\
\hline 3 & Students can access the links / resources easily. & 3.45 & 1.03 & 73.7 & High \\
\hline 4 & $\begin{array}{l}\text { Students post their replies and assignment to the social media } \\
\text { activities easily. }\end{array}$ & 3.48 & 0.92 & 72.6 & High \\
\hline 2 & $\begin{array}{l}\text { Students understand the linguistic content of social media } \\
\text { activities. }\end{array}$ & 3.52 & 1.01 & 68.4 & Moderate \\
\hline & $\begin{array}{l}\text { students' attitudes towards using social media as a tool of } \\
\text { writing of Arabic language. }\end{array}$ & 3.62 & 1.03 & 73.6 & High \\
\hline
\end{tabular}

Table (5) shows that the students' attitudes towards using social media as a tool of writing in Arabic language achieved a mean of (3.62) and a percentage of (73.6), which means that students' have positive attitudes towards using social media as a tool of writing in Arabic.

\section{Results related to the second question}

- What are the kinds of impact that social media has on the students' writing competence?

To answer this question, the researcher calculated the means, standard deviations, percentages, levels, and ranks for types of impact that social media has on the students' writing competence. Table (6) shows the results.

Table (6): Means, standard deviation, percentages and levels of types of impact that social media has on the students' writing competence

\begin{tabular}{|c|c|c|c|c|c|}
\hline No & Item & $\mathrm{M}$ & SD & Percentage & Level \\
\hline 3 & $\begin{array}{llll}\begin{array}{l}\text { Social } \\
\text { productivity }\end{array} & \begin{array}{l}\text { media } \\
\text { in writing. }\end{array} & \text { increases } & \text { students' } \\
\end{array}$ & 3.78 & 1.00 & 73.4 & High \\
\hline 2 & $\begin{array}{l}\text { Social media encourages students to } \\
\text { contribute to the writing skill. }\end{array}$ & 3.66 & 0.98 & 72.6 & High \\
\hline 7 & $\begin{array}{l}\text { Social media can motivate students into } \\
\text { more active and interactive writing. }\end{array}$ & 3.58 & 1.07 & 72.0 & High \\
\hline 4 & $\begin{array}{l}\text { Social media connects students with their teachers at } \\
\text { home. }\end{array}$ & 3.60 & 1.10 & 71.4 & High \\
\hline 8 & Social media enriches students' knowledge to write. & 3.54 & 0.99 & 71.2 & High \\
\hline 1 & $\begin{array}{l}\text { Social media stimulates your students' interest in } \\
\text { writing in Arabic. }\end{array}$ & 3.48 & 1.01 & 70.8 & High \\
\hline 6 & $\begin{array}{l}\text { Social media enables students to view and edit their } \\
\text { writing easily. }\end{array}$ & 3.45 & 0.91 & 69.4 & Moderate \\
\hline 9 & $\begin{array}{l}\text { Social media } \quad \text { improves students' ability } \\
\text { in grammar. }\end{array}$ & 3.42 & 1.12 & 67.0 & Moderate \\
\hline 5 & $\begin{array}{l}\text { Social media has a negative effect on students' } \\
\text { proper spelling. }\end{array}$ & 3.12 & 1.26 & 63.4 & Moderate \\
\hline & Total score of types of impact & 3.51 & 0.61 & 70.13 & High \\
\hline
\end{tabular}

Table (6) shows that the types of impact that social media has on the students' writing competence achieved a mean of (3.51) and a percentage of (70.13), which means that there is an impact that social media has on the students' writing competence.

\section{Results related to the third question}

- What are the effects of social media on the students' writing proficiency, with respect to gender and location? 
The researcher calculated the means, standard deviations, percentages, levels, and ranks for the effects of social media on the students' writing proficiency, with respect to gender and location. Table (7) shows the results.

Table (7): Means, standard deviation, percentages, and levels of the effects of social media on the students' writing proficiency; with respect to gender and location

\begin{tabular}{|c|l|c|c|c|c|}
\hline No & \multicolumn{1}{|c|}{ Item } & M & SD & Percentage & Level \\
\hline 7 & $\begin{array}{l}\text { Social media helps to keep students in } \\
\text { communication with each other despite of the } \\
\text { geographical distances. }\end{array}$ & 3.90 & 0.99 & 75.2 & High \\
\hline 8 & $\begin{array}{l}\text { The more the students use the social media, the } \\
\text { better their writing competence }\end{array}$ & 3.78 & 1.10 & 76.8 & High \\
\hline 5 & $\begin{array}{l}\text { The Social culture of my area effects the use of } \\
\text { social media. }\end{array}$ & 3.42 & 1.08 & 72.4 & High \\
\hline 4 & $\begin{array}{l}\text { The availability of internet service centers and } \\
\text { facilities are limited. }\end{array}$ & 3.46 & 1.12 & 71.6 & High \\
\hline 6 & $\begin{array}{l}\text { The student's weaknesses in reading and/or can be } \\
\text { partially solved by enabling them to use social } \\
\text { media. }\end{array}$ & 3.72 & 1.03 & 70.1 & High \\
\hline 1 & $\begin{array}{l}\text { Students writing proficiency is limited in rural } \\
\text { areas due to the lack of internet facilities. }\end{array}$ & 3.56 & 1.13 & 67.8 & Moderate \\
\hline 3 & $\begin{array}{l}\text { Male students have access to social media more } \\
\text { than females. }\end{array}$ & 3.44 & 1.16 & 68.6 & Moderate \\
\hline 2 & $\begin{array}{l}\text { The competences of female students in Arabic } \\
\text { writing is better than their male counterparts. }\end{array}$ & 3.48 & 1.07 & 69.2 \\
\hline
\end{tabular}

Table (7) shows that the effects of social media on the students' writing proficiency; with respect to gender and location achieved a mean of (3.60) and a percentage of (71.46), which means that there is high significant effect of social media on the students' writing proficiency; with respect to gender and location.

\subsubsection{Results related to the study hypotheses}

\section{Results related to the first hypotheses}

- $\quad$ There are no statistically significant differences at $(\alpha \leq 0.05)$ in the effect of using social media on Jordanian $10^{\text {th }}$ graders' Arabic writing proficiency due to gender.

The researcher used T-Test for independent samples. Table (8) shows the results.

Table (8): T-Test for independent samples of the differences of the effect of social media on Jordanian $10^{\text {th }}$ graders' Arabic writing proficiency due to gender

\begin{tabular}{|l|c|c|c|c|c|c|}
\hline \multirow{2}{*}{ Domain } & \multicolumn{2}{c|}{$\begin{array}{c}\text { Male } \\
(\mathrm{N}=591)\end{array}$} & \multicolumn{2}{c|}{$\begin{array}{c}\text { Female } \\
(\mathrm{N}=473)\end{array}$} & \multirow{2}{*}{$\begin{array}{c}\text { T- } \\
\text { value }\end{array}$} & Sig.* \\
\cline { 2 - 6 } & Mean & S. D & Mean & S. D & & \\
\hline The students' attitudes & 3.66 & 0.70 & 3.32 & 0.72 & 1.086 & 0.278 \\
\hline Type of impact & 3.40 & 0.62 & 3.58 & 0.48 & 1.819 & 0.069 \\
\hline The effect of social media & 3.48 & 0.58 & 3.78 & 0.60 & 1.517 & 0.130 \\
\hline \multicolumn{1}{|c|}{ Total score } & 3.51 & 0.63 & 3.56 & 0.60 & 1.717 & 0.086 \\
\hline
\end{tabular}

\footnotetext{
* Significant at ( $\quad 0.05)$, D.F $=1092$
}

Table (8) shows that there are no significant differences at $(\alpha=0.05)$ in the effect of social media on 8 Jordanian $10^{\text {th }}$ graders' Arabic writing proficiency due to gender.

\section{Results related to the second hypotheses}

There are no statistically significant differences at $(\alpha \leq 0.05)$ in the effect of using social media on Jordanian $10^{\text {th }}$ graders' Arabic writing proficiency due to academic qualification.

The researcher used One-Way ANOVA to test the hypotheses. Tables (9-10) show the frequencies, means and standard deviations of the effect of social media on Jordanian $10^{\text {th }}$ graders' Arabic writing proficiency due to academic qualifications and the results of One-Way ANOVA respectively. 
Table (9): Frequencies, means, and standard deviations of the effect of social media on Jordanian $10^{\text {th }}$ graders' Arabic writing proficiency due to academic qualifications

\begin{tabular}{|c|c|c|c|c|}
\hline Domain & Academic Qualifications & $\mathrm{N}$ & Mean & SD \\
\hline \multirow{2}{*}{ The students' attitudes } & Bachelor & 113 & 3.60 & 0.71 \\
\hline & Master & 23 & 3.56 & 0.55 \\
\hline \multirow{2}{*}{ Type of impact } & Bachelor & 113 & 3.46 & 0.52 \\
\hline & Master & 23 & 3.58 & 0.54 \\
\hline \multirow{2}{*}{ The effect of social media } & Bachelor & 113 & 3.60 & 0.66 \\
\hline & Master & 23 & 3.54 & 0.62 \\
\hline \multicolumn{2}{|c|}{ Total score } & & 3.56 & 0.60 \\
\hline
\end{tabular}

Table (10): One-Way ANOVA to test the differences of the effect of social media on Jordanian $10^{\text {th }}$ graders' Arabic writing proficiency due to academic qualifications

\begin{tabular}{|c|c|c|c|c|c|c|}
\hline Domain & Source of variance & Sum of Squares & D.F & $\begin{array}{c}\text { Mean } \\
\text { Squares }\end{array}$ & $\mathrm{F}$ & Sig.* \\
\hline \multirow{3}{*}{ The students' attitudes } & Between groups & 12.408 & 3 & 4.134 & \multirow{3}{*}{7.936} & \multirow{3}{*}{$\begin{array}{c}* \\
0.001\end{array}$} \\
\hline & Within groups & 567.842 & 1090 & 0.522 & & \\
\hline & Total & 580.243 & 1093 & & & \\
\hline \multirow{3}{*}{ Type of impact } & Between groups & 5.238 & 3 & 1.748 & \multirow{3}{*}{5.322} & \multirow{3}{*}{$\begin{array}{c}* \\
0.001\end{array}$} \\
\hline & Within groups & 357.334 & 1090 & 0.326 & & \\
\hline & Total & 362.566 & 1093 & & & \\
\hline \multirow{3}{*}{ The effect of social media } & Between groups & 1.254 & 3 & 0.422 & \multirow{3}{*}{1.362} & \multirow{3}{*}{$\begin{array}{c}* \\
0.250\end{array}$} \\
\hline & Within groups & 335.942 & 1090 & 0.312 & & \\
\hline & Total & 337.205 & 1093 & & & \\
\hline Total score & Between groups & 5.232 & 3 & 1.744 & 6.504 & $\begin{array}{c}* \\
0.001\end{array}$ \\
\hline
\end{tabular}

Significant at $(\alpha=0.05)$

Table (10) indicates that there are no significant differences at $(\alpha=0.05)$ in the effect of social media on Jordanian $10^{\text {th }}$ graders' Arabic writing proficiency due to academic qualifications in the domain of the effect of social media while there are significant differences at $(\alpha=0.05)$ in the effect of social media on Jordanian $10^{\text {th }}$ graders' Arabic writing proficiency due to academic qualifications in the domains of the students' attitudes, type of impact and total score.

The researcher used Scheffe post hoc test to determine the source of differences. Tables (11-12) show Scheffe post hoc test results.

Table (11): Scheffe post hoc results to determine the differences in domain of the students' attitudes due to academic qualifications

\begin{tabular}{|c|c|c|}
\hline Academic qualifications & Bachelor & Master \\
\hline Bachelor & & -0.100 \\
\hline Master & $-0.440 *$ & \\
\hline
\end{tabular}

\footnotetext{
*Significant at $(\alpha=0.05)$
}

Table (11) shows that: There are significant differences at $(\alpha=0.05)$ in the effect of social media on Jordanian $10^{\text {th }}$ graders' Arabic writing proficiency due to academic qualifications in the domain of students' attitudes, between bachelor and M. A/M.SC degrees in favor of getting M. A/M.SC degree.

Table (11): Scheffe post hoc results to determine the differences in domain of the kind of impact due to academic

\begin{tabular}{|c|c|c|}
\hline \multicolumn{2}{|c|}{ qualifications } & Machelor \\
\hline Academic Qualifications & & -0.102 \\
\hline Bachelor & $-0.322 *$ & \\
\hline Master & & \\
\hline
\end{tabular}

\footnotetext{
*Significant at $(\alpha=0.05)$
}

Table (11) shows that: There are significant differences at $(\alpha=0.05)$ in the effect of social media on Jordanian $10^{\text {th }}$ graders' Arabic writing proficiency due to academic qualification in the domain of type of impact, between bachelor and M. A/M.SC degrees in favor of getting M. A/M.SC degree. 
Table (12): Scheffe post hoc results to determine the differences in total score due to academic qualifications

\begin{tabular}{|c|c|c|}
\hline Academic qualifications & Bachelor & Master \\
\hline Bachelor & & $-0.306^{*}$ \\
\hline Master & -0.097 & \\
\hline
\end{tabular}

*Significant at $(\alpha=0.05)$

Table (12) shows that: There are significant differences at $(\alpha=0.05)$ in the effect of social media on Jordanian $10^{\text {th }}$ graders' Arabic writing proficiency due to academic qualification in the total score, between bachelor and $\mathrm{M}$. A/M.SC degrees in favor of getting M. A/M.SC degree.

\section{Results Related to the Third Hypotheses}

- There are no statistically significant differences at $(\alpha \leq 0.05)$ in the effect of using social media on Jordanian $10^{\text {th }}$ graders' Arabic writing proficiency due to educational experience.

The researcher used One-Way ANOVA to test the hypotheses. Tables (13-14) show the frequencies, means and standard deviations of the effect of social media on There are no statistically significant differences at $(\alpha \leq$ 0.05 ) in the effect of using social media on Jordanian $10^{\text {th }}$ graders' Arabic writing proficiency due to educational experience, writing proficiency due to Educational Experience and the results of One-Way ANOVA respectively. Table (13): Frequencies, means, and standard deviations of the effect of social media on There are no statistically significant differences at $(\alpha \leq 0.05)$ in the effect of using social media on Jordanian $10^{\text {th }}$ graders' Arabic writing proficiency due to educational experience.

\begin{tabular}{|c|c|c|c|c|}
\hline Domain & Educational Experience & $\mathrm{N}$ & Mean & SD \\
\hline \multirow{3}{*}{ The students' attitudes } & Less than 5 years & 16 & 3.68 & 0.62 \\
\cline { 2 - 5 } & $5-10$ years & 43 & 3.82 & 0.68 \\
\cline { 2 - 5 } & More than 10 years & 77 & 3.46 & 0.78 \\
\hline \multirow{3}{*}{ Type of impact } & Less than 5 years & 16 & 3.44 & 0.52 \\
\cline { 2 - 5 } & 5-10 years & 43 & 3.58 & 0.56 \\
\cline { 2 - 5 } The effect of social media & More than 10 years & 77 & 3.84 & 0.68 \\
\cline { 2 - 5 } & Less than 5 years & 16 & 3.62 & 0.58 \\
\cline { 2 - 5 } & 5-10 years & 73 & 3.50 & 0.52 \\
\hline \multicolumn{2}{|c|}{ Total score than 10 years } & 3.56 & 0.58 \\
\hline
\end{tabular}

Table (14): One-Way ANOVA to test the differences of the effect of social media on Jordanian $10^{\text {th }}$ graders' Arabic writing proficiency due to Educational Experience

\begin{tabular}{|c|c|c|c|c|c|c|}
\hline Domain & Source of variance & Sum of Squares & D.F & Mean Squares & $\mathrm{F}$ & Sig.* \\
\hline \multirow{3}{*}{$\begin{array}{l}\text { The students' } \\
\text { attitudes }\end{array}$} & Between groups & 28.145 & 2 & 14.114 & \multirow{3}{*}{27.784} & \multirow{3}{*}{$\begin{array}{c}* \\
0.001\end{array}$} \\
\hline & Within groups & 552.202 & 1091 & 0.506 & & \\
\hline & Total & 580.336 & 1093 & & & \\
\hline \multirow{3}{*}{ Type of impact } & Between groups & 5.620 & 2 & 2.244 & \multirow{4}{*}{8.546} & \multirow{4}{*}{$\begin{array}{c}* \\
0.001\end{array}$} \\
\hline & Within groups & 356.785 & 1091 & 0.422 & & \\
\hline & Total & 362.124 & 1093 & & & \\
\hline \multirow{3}{*}{$\begin{array}{l}\text { The effect of } \\
\text { social media }\end{array}$} & Between groups & 1.624 & 2 & 0.802 & & \\
\hline & Within groups & 335.253 & 1091 & 0.421 & \multirow[t]{2}{*}{2.307} & \multirow[t]{2}{*}{0.100} \\
\hline & Total & 336.870 & 1093 & & & \\
\hline \multirow{3}{*}{ Total score } & Between groups & 9.251 & 2 & 4.422 & \multirow{3}{*}{17.035} & \\
\hline & Within groups & 282.462 & 1091 & 0.242 & & \\
\hline & Total & 291.746 & 1093 & & & \\
\hline
\end{tabular}

*Significant at $(\alpha=0.05)$

Table (14) indicates that there are no significant differences at $(\alpha=0.05)$ in the effect of social media on Jordanian $10^{\text {th }}$ graders' Arabic writing proficiency due to Educational Experience to in the domain of the effect of social media while there are significant differences at $(\alpha=0.05)$ in the effect of social media on Jordanian $10^{\text {th }}$ graders' Arabic writing proficiency due to Educational Experience in the domains of the students' attitudes, type of impact and total score. The researcher used Scheffe post hoc test to determine the source of differences. 
Table (15): Scheffe post hoc results to determine the differences in domain of the students' attitudes due to Educational Experience

\begin{tabular}{|c|c|c|c|}
\hline Educational Experience & Less than 5 years & $5-10$ years & More than 10 years \\
\hline Less than 5 years & & 0.108 & $0.393^{*}$ \\
\hline 5-10 years & & & $0.285^{*}$ \\
\hline More than 10 years & & & \\
\hline
\end{tabular}

*Significant at $(\alpha=0.05)$

Table (15) shows that: There are significant differences at $(\alpha=0.05)$ in the effect of social media on Jordanian $10^{\text {th }}$ graders' Arabic writing proficiency due to Educational Experience in the domain of students' attitudes, between less than 5 years and more than 10 years in favor of less than 5 years. There are significant differences at $(\alpha=0.05)$ in the effect of social media on Jordanian $10^{\text {th }}$ graders' Arabic writing proficiency due to Educational Experience in the domain of students' attitudes, between 5- 10 years and more than 10 years in favor of 5-10 years.

Table (16): Scheffe post hoc results to determine the differences in domain of the kind of impact due to Educational Experience

\begin{tabular}{|c|c|c|c|}
\hline Educational Experience & Less than 5 years & 5-10 years & More than 10 years \\
\hline Less than 5 years & & 0.062 & $0.178^{*}$ \\
\hline 5-10 years & & & $0.124^{*}$ \\
\hline More than 10 years & & & \\
\hline
\end{tabular}

*Significant at $(\alpha=0.05)$

Table (16) shows that: There are significant differences at $(\alpha=0.05)$ in the effect of social media on Jordanian $10^{\text {th }}$ graders' Arabic writing proficiency due to Educational Experience in the domain of type of impact, between less than 5 years and more than 10 years in favor of less than 5 years. There are significant differences at $(\alpha=0.05)$ in the effect of social media on Jordanian $10^{\text {th }}$ graders' Arabic writing proficiency due to Educational Experience in the domain of type of impact, between 5-10 years and more than 10 years in favor of 5-10 years.

Table (17): Scheffe post hoc results to determine the differences in total score due to Educational Experience

\begin{tabular}{|c|c|c|c|}
\hline Educational Experience & Less than 5 years & $5-10$ years & More than 10 years \\
\hline Less than 5 years & & 0.074 & $0.228^{*}$ \\
\hline 5-10 years & & & $0.154^{*}$ \\
\hline More than 10 years & & & \\
\hline
\end{tabular}

*Significant at $(\alpha=0.05)$

Table (17) shows that: There are significant differences at $(\alpha=0.05)$ in the effect of social media on Jordanian $10^{\text {th }}$ graders' Arabic writing proficiency due to Educational Experience in the total score, between less than 5 years and more than 10 years in favor of less than 5 years. There are significant differences at $(\alpha=0.05)$ in the effect of social media on Jordanian $10^{\text {th }}$ graders' Arabic writing proficiency due to Educational Experience in the total score, between 5-10 years and more than 10 years in favor of 5-10 years.

\subsubsection{Results Related to the Standardized Writing Test}

- There are no significant differences at $(\alpha=0.05)$ in the writing skill due to the two groups: controlled group and experimental group.

The researcher used T-Test for independent samples. Table (34) shows the results.

Table (18): T-Test for independent samples of writing skill due to groups

\begin{tabular}{|c|c|c|c|c|c|c|}
\hline \multirow[b]{2}{*}{ skill } & \multicolumn{2}{|c|}{ Control $(\mathrm{N}=120)$} & \multicolumn{2}{|c|}{ experimental $(\mathrm{N}=120)$} & \multirow{2}{*}{$\begin{array}{c}\mathrm{T}- \\
\text { value }\end{array}$} & \multirow[b]{2}{*}{ Sig.* } \\
\hline & $\mathrm{M}$ & S. D & $\mathrm{M}$ & S. D & & \\
\hline Syntax & 0.84 & 0.46 & 0.86 & 0.64 & 1.942 & $0.050 *$ \\
\hline Semantics & 1.01 & 0.58 & 1.32 & 0.62 & 2.646 & $0.010^{*}$ \\
\hline Dictation & 0.76 & 0.54 & 1.02 & 0.64 & 1.810 & 0.072 \\
\hline Organization & 1.25 & 0.64 & 1.42 & 0.78 & 2.272 & $0.024 *$ \\
\hline Total & 3.93 & 2.04 & 4.62 & 1.99 & 2.292 & $0.023 *$ \\
\hline
\end{tabular}

\footnotetext{
* Significant at $(0.05)$, D.F $=178$
}

Table (18) indicates that there are no significant differences at $(\alpha=0.05)$ in the analysis item for the writing skill: dictation. While there are significant differences in the analysis items for the writing skill: syntax, semantics and organization due to the groups, in favor of the experimental group.

\subsection{Conclusion}

7.1.1. Discussion of the results of the first question

- What is the effect of using social media on Jordanian $10^{\text {th }}$ graders' Arabic writing proficiency in Amman 
schools?

Results showed the following: The students' attitudes towards using social media as a tool of writing in Arabic language, the findings of items (1-9) in table (5) showed that using social media on Jordanian $10^{\text {th }}$ graders' Arabic writing proficiency has positive attitudes. The total average which investigated the students' Arabic writing proficiency, was " 73.6\%" with high effect. The researcher believes that the reason behind that is the growing trends for the $10^{\text {th }}$ graders' towards using social media which aims to create active and self-dependent learners in the writing skill through achieving a variety of goals or functions including doing homework and reviewing tests. In response to items $(1 \& 2)$, item $(1)$ received a high effect degree, most students $(72.4 \%)$ which reported students can write activities in his language through utilizing social media. Social media encourages a wider range of expressive capacity and Allaith \& Joshi (2008) agreed that social media comprises of activities that involve socializing. It is redefining how we relate to each other as humans and how we as humans relate to the organizations that serve us. But item (2) received a moderate effect degree, most students (68.4\%). This finding agrees with (Alsaawi, 2015; Byrne, 1997) who found that writing is considered difficult even in the mother tongue because of these three factors; psychological, linguistic and cognitive. From the psychological side, when students write, their writing will improve to be solitary activity, so students must write without possible interaction or feedback.

The results of items $(3 \& 4)$ received a high effect degree, the majority of students $(73.7 \%)$ and $(72.6 \%)$ reported that students can access the links and post their replies easily through using social media, and the items ( 5 \& 6) findings agree with Petrina (2007), who argues that the tools of the trade are as important as the learning objectives, and that tools are needed which promote social presence, create a more interactive learning environment and foster collaborative study. Most students (72.6\% - 73.6\%) and received a high effect degree. But Zepke \& Leach (2010) suggest that motivation and student dispositions will influence their ability to engage in interactive learning, where the line between online learning and socialization is blurred as well as the item (7) majority of students $(73.6 \%)$ and received a high effect degree. The findings of items ( 8 and 9$)$ strongly confirmed that students prefer to write and work well in groups through social media. The effect degree on these items was high with the percentage of response on them respectively was $(71.2 \%)$ and $76.2 \% "$. These findings agree with Junco (2011) who shows that more emphasis must be placed on learning with technology. The default setting for many academics remains on teaching with technology.

7.1.2. Discussion of the Results of the second question: The kinds of impact that social media has on the students' writing competence.

The findings of items (1-9) in table (6) showed that, using social media has positive impact on the students' writing competence in Amman schools. The total average which investigated the impact on the students' Arabic writing competence, was $(70.13 \%)$ with high effect which indicated that students believe that writing skill is fundamental skill to succeed and perform well through using social media. Moreover, the results indicated that most teachers agreed on the usefulness of employing social media as a study tool during lessons and for writing skill. Students confirmed that social media helps them in providing the opportunity to share information with their classmates. The results to items $(1 \& 2)$ agree with Sharawneh (2012) who found that the assessment of the writing ability among language teachers and students has always been important because the results of such an evaluation are used for a variety of administrative, instructional and research purposes. Teachers use these results to help improve, influence, refine and shape their students' attained writing ability, and Fareh (2014) who found that social media has several effects on academic work.

The results of items $(3 \& 4)$ received a high effect degree, most students $(73.4 \%)$ and $(71.4 \%)$ reported that social media can increase students' productivity in writing and helps to connect students with their teachers at home. But the items (5\& 6) findings disagree with Alsaawi (2015) who discussed a three- phase framework of teaching to write. Most students (61.4\%) and (69.4\%) and received a moderate effect degree. On the other hand, the findings of items (7and 8) strongly confirmed that students can motivate to be more active and enrich students' knowledge to write through social media. The effect degree on these items was high with the percentage of response on them respectively was $(72.0 \%$ \& $71.2 \%)$ These findings agree with Zepke \& Leach (2010) who suggested that motivation and student dispositions will influence their ability to engage in interactive learning, where the line between online learning and socialization is blurred, Junco (2011) who emphasized that online discussions direct teenagers into self- learning and create opportunities for them to develop critical thinking and argumentation skills. However, the finding of item (9) received a moderate effect degree, most students (67.0\%). This finding disagrees with Khailani \& Muqattash (1996), and Ghanem, M (2016) who mentioned five pedagogical purposes for teaching writing.

7.1.3. Discussion of the Results of the third question: The effect of social media has on the students' writing proficiency; with respect to gender and location.

The findings of items (1-8) in table (7) showed that social media has positive effect on the students' writing proficiency with respect to gender and location. The total average for the third domain which investigated the high effect on the students' Arabic writing proficiency, was (71.4\%) with high effect which indicated that, more students use the social media, the better their writing competence. Additionally, the results indicated that most teachers 
agreed on the good effect of using social media as a study tool during lessons and at home; with respect to gender and location. Students confirmed that social media helps them to keep in communication with each other despite the geographical distances and gender; male or female. The results to items (1-8) received a high effect degree, most students $(73.4 \%, 71.4 \%, 70.8 \%, 71.8 \%, 70.0 \%, 77.0 \%$ and $76.6 \%)$.

\subsubsection{Discussion the Results of Hypotheses of the study}

The first hypotheses states that: There are no statistically significant differences at $(\alpha \leq 0.05)$ in the effect of using social media on Jordanian $10^{\text {th }}$ graders' Arabic writing proficiency due to gender. After data analysis, it was found that there are no significant differences at $(\alpha=0.05)$ in the effect of social media on Jordanian $10^{\text {th }}$ graders of Arabic writing proficiency due to gender. The researcher used T-Test for independent samples.

The data analysis of the second hypotheses: There are no statistically significant differences at $(\alpha \leq 0.05)$ in the effect of using social media on Jordanian $10^{\text {th }}$ graders' Arabic writing proficiency due to academic qualification. The researcher used One-Way ANOVA to test the hypotheses. The results revealed that there are no significant differences at $(\alpha=0.05)$ in the effect of social media on Jordanian 10th graders of Arabic writing proficiency due to academic qualification in the domain of the effect of social media while there are significant differences at $(\alpha=$ 0.05 ) in the effect of social media on Jordanian $10^{\text {th }}$ graders of Arabic writing proficiency due to academic qualification in the domains of students' attitudes, type of impact and total score. The researcher used Scheffe post hoc test to determine the source of differences.

The data analysis of the third hypotheses," There are no statistically significant differences at $(\alpha \leq 0.05)$ in the effect of using social media on Jordanian $10^{\text {th }}$ graders' Arabic writing proficiency due to educational experience. The results revealed that there are no significant differences at $(\alpha=0.05)$ in the effect of social media on Jordanian 10th graders of Arabic writing proficiency due to educational experience. The researcher used One-Way ANOVA to test this hypothesis.

\subsubsection{Discussion the Results of the Standardized Writing Test}

The data analysis of the standardized writing test," There are significant differences at $(\alpha=0.05)$ in the writing skill: syntax, semantics, organization and dictation due to the groups, in favor of the experimental group."

The results showed that there are no significant differences at $(\alpha=0.05)$ in the effect of social media on Jordanian 10th graders of Arabic writing proficiency due to groups.

The participants recorded better stances of their attitudes towards improving their writing after being involved in the social media's writing activities. The students' responses show how social media helped to develop their writing ability and enabled them to view and edit their writing easily. The students also reported that social media enriched their writing content and structure. This means that participants have positive attitude towards writing through social media and would like to use it in the study of other Arabic language skills.

\subsection{Conclusions}

8.1.1. Social Media provided students with a better learning environment that was positively reflected on their writing achievement of Arabic language.

8.1.2. Social Media motivated students towards an independent practice of Arabic language instead of direct directions. This was clear through group work activities and their asking for extra computer lab time during the social media inclusion experiment to check the editing status or to edit for themselves or for another student.

8.1.3. Social Media developed collaborative writing among participants. This was clear because students learned through idea exchange and learned from their own mistakes as well as the mistakes of their partners. Social media provided great opportunities for low and intermediate achievers to get involved with high achievers and learn from them.

8.1.4. Social Media is a very beneficial technology tool for teaching Arabic writing where participants in the experiment showed remarkable improvement in the experimental writing test.

8.1.5. Social Media helped participants build a sense of leadership because groups always have leaders.

\subsection{Recommendations}

\subsubsection{For the Teacher}

- Activating the role of social media-based technology in Changing teachers' role from instructors who dominate the class into educators whose role is to help, guide and support teachers and their students to acquire language.

- Enriching the curriculum with relevant social media technology that enhances students' use of Arabic language inside and outside school.

- Equipping the classrooms with computers and connect them appropriately with the internet and then connect all of the schools freely with the internet. 


\subsubsection{For the Student}

- Students developed collaborative writing among using social media. This was clear, because students learned through idea exchange and learned from their own mistakes as well as the mistakes of their partners.

- Students used the attitudes on the right track and helped to develop knowledge of the written language.

\subsubsection{For the School}

- Conducting training courses that help teachers enhance their competencies of implementing social mediabased technology in their classes.

- Conducting workshops that aim at familiarizing teachers with different techniques and strategies used in the wiki technology.

\section{References}

Abdullah, S. (2015), Exploring the Use and the Impacts of Social Media on Teaching and Learning Science in Saudi. Procedia - Social and Behavioral Sciences, [online], 182, 13, 213-224, available, https://www.sciencedirect.com/science/article/pii/S1877042815030335.

Abed, Z. (2012). The Role of Social Communication Networks in Mobilizing the Palestinian Public Opinion Toward Socio-Political Change. Unpublished Master's thesis, Al-Aqsa University, Palestine.

Albawe, F., \& Stanley, A. (2014). A study on the use of educational technology to develop English language writing skills of efl Libyan university students. Research Journal of English Language and Literature. 2(4), 259-271.

Allaith, Z.A., \& Joshi, R.M. (2011). Spelling performance of English consonants among students whose first language is Arabic. Reading and Writing, 24(9), 1089-1110.

Alsaawi, A. (2015). Spelling Errors Made by Arab Learners of English. International Journal of Linguistics, 7 , (5), 55-67.

Alshohry, H. (2014). The Effects of Using Electronic Social Networks on Social Relationships Facebook and Twitter as Example. Unpublished Master's thesis, King Abdul Aziz University, K.S.A.

Alshrouf, M. (2018). The Effect of Using Internet on Developing Writing Expression and Oral Expression Skills in Arabic Language Course Among Basic Ninth Class Students, Unpublished Master's thesis. Amman Arab University, Jordan.

Byrne, D. (1997). Teaching Writing Skills, (Longman Handbooks for Language Teachers). New York: Longman Group UK Limited.

Crook, C, (2008), Web 2.0 Technologies for Learning: The Current Landscape - Opportunities, Challenges and Tensions, [online], available: http//dera.ioe.ac.uk/1474/1/becta_2008_web2_currentlandscape_litrev.pdf (12/November/2020).

Duncan, E., \& Barnett, J. (2010). Experiencing online pedagogy: a Canadian case study. Teaching Education. 21 (3), 247-262.

Fareh, S. (2014). Macro linguistic Errors in Arab EFL Learners' Essays. Procedia-Social and Behavioral Sciences, $141,923-933$.

Ghanem, M. (2016). The Impact of Using Google Applications as a Vehicle to Increase Sixth Grade Students' Scientific Concepts Acquisition and their Attitudes toward the Acceptance of Technology in Tulkarm Governmental Schools, Unpublished master's thesis, An-Najah National University.

Harmer, J. (2004). How to Teach Writing. England: Person Educational Limited.

Isa, H. (2012). The Effect of Using Wikis on Improving Palestinian $9^{\text {th }}$ Graders' English Writing Skills and their Attitudes towards Writing, Unpublished master's thesis, The Islamic University of Gaza.

Junco, R, (2011). Too Much Face and not Enough Books: The Relationship Between Multiple Indices of Facebook Use and Academic Performance. Computers in Human Behavior, [on line], availbale: http://psycnet.apa.org/record/2011-25835-021

Khailani, T., \& Muqattash, L. (1996). Methodology II. 1st ed. Jordan: Al Quds open University.

Kissler, L. (2010). Connect. ED: promoting higher education via social media to millennial, Eastern Washington University, Cheney, Washington.

Langer, N. (2014). Alexandra Jaffe, Jannis Androutsopoulos, Mark Sebba, Sally Johnson (eds.): Orthography as Social Action: Scripts, Spelling, Identity and Power (Language and Social Processes 3). Language Policy, 13.

Lindsay, C., \& Knight, P. (2006). Learning and Teaching English. A Course for Teachers: Oxford University Press.

Mhunpiew, N., \& Purayidathil, J. (2015). Social Networks as a Tool for Education: An Awareness of School Leaders. US-China Education Review. [on line] available,

http://www.davidpublisher.org/Public/uploads/Contribute/5508d3f94e 6f9.pdf. 
Mills, N. (2011). Situated Learning through Social Networking Communities: The Development of Joint Enterprise, Mutual Engagement, and a Shared Repertoire. CALICO Journal, 28 (2), 345-368. [on line] available, http://www.jstor.org/stable/calicojournal.28.2.345.

Murad, T., \& Khalil, M. (2015). Analysis of Errors in English Writings Committed by Arab First-year College Students of EFL in Israel. Journal of Language Teaching and Research, 6 (3), 475-481.

Nassar, D. (2016). Using Social Network as an Education Enhancement Tools A Case Study of Using Whatsapp in Princess, Nourah University. Journal of Educational and Instructional Studies in The World, [on line] available: http://www.wjeis.org/FileUpload/ds217232/File/04.dua'_abdalltef_nassar.pdf. (14/12/2020)

National Commission on Writing. (2003). The neglected " $r$ ": The need for a writing revolution. New York: The College Entrance Examination Board.

Petrina, S. (2007). Advance Teaching Methods for the Technology Classroom, 125-153. Hershey, PA : Information Science Publishing.

Reershemius, G. (2017). Autochthonous Heritage Languages and Social Media: Writing and Bilingual Practices in Low German on Facebook, Journal of Multilingual and Multicultural Development, [on line] available: https://eric.ed.gov/?q=social+media+and+writing\&id=EJ1132622 (11/12/2020).

Robert, A. (2009). The dynamics of language. In the Encyclopedia of Complexity and system science, SpringerVerlag, Heidelberg, 2310.2323.

Sabine, G., Kinshuk, \& Liu, T. C. (2009). Supporting Teachers in Identifying Students' Learning Styles in Learning Management Systems: An Automatic Student Modelling Approach. Educational Technology \& Society, 12 (4), 3-14.

Sharawneh, I. (2012). Evaluation of Assessment Practices in English Writing for High School Palestinian Students: A Critical Study. Unpublished Master's thesis, Hebron University.

Stephanie, V. (2015). What's Going On? Challenges and Opportunities for Social Media Use in the Writing Classroom, [on line] available: https://eric.ed.gov/?q=social+media+on+writing\&id=EJ1134368. $(08 / 11 / 2020)$

Tezci, E., \& Icen, M. (2017). High School Students' Social Media Usage Habits, [on line] available, https://files.eric.ed.gov/full text/ED577955.pdf.(102/12/2020)

Wheeler, S. (2009). Connected Minds, Emerging Cultures. Charlotte, NC: Information Age.

White, C.J. (2004). Independent Language Learning in Distance Education: Current Issues, [on line] available http://independentlearning.org/ILA/ila03/ila03_white.pdf. (05/12/2020)

Zepke, N., \& Leach, L (2005). Integration and adaptation: approaches to the student retention and achievement puzzle, [on line] available: http://journals.sagepub.com/doi/pdf/10.1177/1469787405049946.(04/12/2020)

Fayyoumi, Khalil A. Rahman, I attended and participated in more than (40) events and conferences related to curriculum and instruction, as: Literacy as Freedom, UNESCO, Jordan. Children and the City Conference, Arab Urban Development Institute and World Bank. Jordan E-Learning Forum. Outcomes of Higher Education for Women I have (23) papers published in international journals. Associate Professor at Amman Arab University, Jordan. Chairman, Department of Classroom Teacher, Faculty of Educational, Sciences and Arts, member of the Supervision Committee for Authoring Arabic Textbooks in Jordan, Ministry of Education, Jordan. Member, Jordan Psychological Association. Jordan Society for Scientific Research, Entrepreneurship and Creativity (JSSREC). Association of Educators, Jordan.

Al. Fayyoumi, Moaweyah, Khalil, I hold BSc degree and experiences in Electrical Engineering majoring Power from Al-Balqa' Applied University, Jordan, I am preparing Master degree in Renewable Energy, I’m amembership in Association of Energy Engineers (aee), IEEE, certified in energy, as energy manger (CEM), green building LEED AP BD $+\mathrm{C}$, and recently, certified from Project Management Institute (PMI) as a Risk Management Professional, I,m born in Amman 1990, I has aseveral papers published in international magazines, and an expert in social media technologies. 